The Bangladesh Veterinarian (2008) 25(2) : 51-61

\title{
Breeding soundness of stud bulls
}

\author{
S. P. Shaha, M. G. S. Alam*, M. Khatun and J. U. Ahmed ${ }^{1}$ \\ Department of Surgery and Obstetrics, Faculty of Veterinary Science, Bangladesh \\ Agricultural University, Mymensingh, Bangladesh
}

\begin{abstract}
Four bulls of mixed breeds (Sahiwal $\times$ Zebu, Sindhi $\times$ Zebu, Jersey $\times$ Zebu and Holstein-Friesian $\times$ Zebu )were examined physically and their semen was evaluated in three seasons: I (Rainy): May - November, II (Winter): December - February, III (Summer): March- April. The semen volume, sperm motility, sperm concentration and percentage of dead sperm ranged from 4.1 to $7.6 \mathrm{ml}, 56.6$ to $76 \%, 1010.3$ to $1290.7 \times$ $10^{6} / \mathrm{ml}$ and 18.4 to $24.7 \%$, respectively. All these attributes varied significantly $(\mathrm{p}<0.05)$ between breeds and seasons. The variations of semen quality between breeds were not significant $(\mathrm{p}>0.05)$. It is suggested that the Holstein - Friesian $\times$ Zebu crossbred bull produces better quality semen than others. (Bangl. vet. 2008. Vol. 25, No. 2, 51-61)
\end{abstract}

\section{Introduction}

Breeding soundness refers to a bull's ability to get cows pregnant. Although $20-40 \%$ of bulls may have reduced fertility, few are completely sterile (Kastelic et al., 2000). Sub-fertility in bulls delays pregnancy, prolongs calving interval, reduces calf weaning weight and increases culling rate of females. Multiple sire breeding groups and low breeding pressure may mask sub-fertility, but single-sire mating groups and artificial insemination (AI) increase the importance of bull fertility.

In Bangladesh, cross breeding for upgradation of cattle was started in 1935 with a view to improve the local cattle stock (Ahmed and Islam, 1987), al with no systematic sexual health control programme. Because of low uptake of AI in smallholdings, production per animal has remained very low. To overcome this, a programme should be undertaken for improvement of cattle in Bangladesh, especially indigenous cattle. If pregnancy does not result from the minimum number of services, it constitutes an economic loss to the farmer. AI must be combined with a health control programme, which must take care of sub-fertility problems. AI continues to be the most effective weapon in the control of venereal and other diseases. Single bull in AI centre can produce 100000 doses of semen per year. A single collection of semen may yield over a thousand doses, which may be widely distributed over a long period.

Extremely low reproductive rates in tropical location are often blamed on female cattle, although it may be assumed that climate and poor health may influence the fertility of bulls, especially semen quality and libido (Bloom, 1978). In Bangladesh, comprehensive work has not been done with regard to fertility of cattle by AI. The present study was undertaken to evaluate bulls for breeding soundness.

\footnotetext{
*Correspondence: E-mail:- mgsalam52@yahoo.com
} 


\section{Materials and Methods}

Four cross-bred bulls (Sahiwal $\times$ Zebu, Sindhi $\times$ Zebu, Jersey $\times$ Zebu and Holstein-Friesian $\times$ Zebu) were examined for breeding soundness. The age was determined from the records maintained at the Government and Bangladesh Agricultural University (BAU), Mymensingh AI Centres, and varied from 5 to 10 years. Bulls were maintained under stall feeding and fed approximately $8 \mathrm{~kg}$ roughage and $2 \mathrm{~kg}$ concentrate per day with free access to drinking water. The bulls were allowed to exercise daily for one hour. Meteorological information was obtained and the year was divided into three seasons (Table 1).

Table 1. Average temperature, humidity and rainfall recorded by the Meteorological Department of BAU (1988-89)

\begin{tabular}{lccccc}
\hline & Seasons & Temperature ${ }^{\circ} \mathrm{C}$ & Humidity $(\%)$ & Rainfall $(\mathrm{mm})$ \\
\hline I & Rainy (May-November) & 27.8 & 84.4 & 299.0 \\
II & Winter (December-February) & 20.8 & 77.3 & 5.8 \\
III Summer (March-April) & 26.3 & 74.3 & 86.1 \\
\hline
\end{tabular}

\section{Examination of bulls}

Before introduction to the collection schedule, the bulls were examined physically and for integrity of testes and reproductive tracts as described by Herman et al. (1994). The sexual behaviour of the bulls was observed, including libido, erection, mounting and grasping of the dummy, protrusion of penis and thrust and ejaculation. The scrotum was inspected with respect to size, shape and freedom from skin disease. The scrotal circumference was measured by the method of Chenoweth and Ball (1981).

\section{Semen collection}

The semen was collected twice a week by means of artificial vagina (Arthur et al., 1982). Before collection, warm water was put into the space between the two tubes. Sterile soft petroleum jelly was smeared over the inner surface. The internal temperature of artificial vagina was checked to ensure that it was not above $50^{\circ} \mathrm{C}$. The artificial vagina was held upright to flow the ejaculate into graduated tube which was attached with the latex extension cone.

\section{Semen examination}

Two ejaculates were collected as described by Almaquist (1978) and Herman et al. (1994).

a) Volume and macroscopic examination

The volume, colour and opacity of the semen and presence of any foreign substances were checked according to Comhaire et al. (1992); Mortimer (2000). The 
density of the ejaculate reflects sperm concentration, which was expressed with " $\mathrm{D}$ ". The sperm concentration was determined by a haemocytometric method (Elliott, 1978). The samples of semen with concentration above $1000 \times 10^{6} / \mathrm{ml}$ were considered as good.

b) Mass activity and motility of sperm

A drop of undiluted semen was placed on a warmed $\left(37^{\circ} \mathrm{C}\right)$ slide without cover slip and examined with low power objective $(10 \times)$ as described by Herman et al. (1994). The mass activity was graded as :

$0=$ No mass activity

$+\quad=$ Slow wave motion

$++=$ Rapid wave motion with formation of eddies at the end of waves.

$+++=$ Eddies

Motility was evaluated in a small drop of semen under cover slip with higher magnification (100x). Sperm moving forward were included in the motility count while sperm moving in circles or backward or showing pendulating movement were excluded (Herman et al., 1994).

\section{c) Sperm concentrations}

The concentration of sperm per cubic millilitre for each ejaculate was measured by direct cell count method (Bane, 1952; Elliott, 1978).

d) Semen $\mathrm{pH}$ and sperm viability

The $\mathrm{pH}$ of the semen was determined using indicator paper strips. The live and dead sperm were counted by East Green-Eosin blue stain (Barth and Oko, 1989; Herman et al., 1994; Salisbury et al., 1978).

\section{Results and Discussion}

Breeding soundness evaluation is a practical method to eliminate bulls with unsatisfactory breeding potential. This evaluation was conducted on every bull 30 to 60 days before each breeding period to allow time to replace unsatisfactory bulls. Producers observed bulls with cows in oestrus to determine whether bulls showed the desire and ability to mate successfully. The bulls were all free from venereal diseases. The health of the bulls was good, as suggested by the Theriogenology Society in the United States of America (Kastelic and Thundathil, 2008).

Sexual behaviour of all the bulls was satisfactory. The scrotal sac was normal and no skin lesion was detected. The mean scrotal circumference was $37.12 \pm 1.62 \mathrm{~cm}$. Observation of mating performance and behaviour and semen evaluation are traditionally used to assess bulls for suitability for breeding (Parkinson, 2004). Britol et al. (2004) found scrotal circumference was a good predictor of sexual maturity in 
Bos indicus bulls. Chacón et al. (2002) observed that scrotal circumference is positively related to body condition in Brahman bulls in tropics and commented that nutrition may be a major factor affecting seasonal variations in male reproductive parameters, especially testicular size. Santos et al. (1998) in a study of Zebu bulls found that those fed high levels of concentrates had higher body weight and scrotal circumference than those fed low levels, but there was no difference in semen turbidity, motility and sperm concentration. As scrotal circumference increases, age at puberty decreases and productivity is improved in daughters (Engelken, 2008).

No pathological lesion was detected in the prepuce and penis during inspection. The testicles were freely movable inside the scrotal sac and felt elastic on superficial and deep palpation. Caput epididymis and corpus epididymis of each bull appeared normal; the seminal vesicles were symmetrical, lobulated and normal in consistency on rectal examination. The ampullae were symmetrical and had no signs of inflammation. The inguinal rings of all bulls allowed easy entrance of one or two fingers at rectal examination. Barth (2007) reviewed the common abnormalities of the accessory sex glands.

Male fertility is commonly defined in terms of the conventional semen profile, which describes the number of motile sperm in the ejaculate. Any mammalian ejaculate constitutes a heterogeneous population of sperm presenting three or four sperm subpopulations with specific patterns of movement, and this has been suggested to be a widespread phenomenon among mammalian ejaculates (Abaigar $e t$ al., 1999; Quintero-Moreno et al., 2003). The semen characteristics of bulls in our study are presented in Table 2 .

\section{Volume}

Significantly $(\mathrm{p}<0.05)$ highest $(7.6 \mathrm{ml})$ volume of semen was in Holstein-Friesian $\times$ Zebu crosses and lowest $(4.0 \mathrm{ml})$ in Sahiwal $\times$ Zebu (Table 2). Sane et al., (1994) found that the mean volume of the ejaculate in adult dairy and buffalo bulls was 5.4 to $6.5 \mathrm{ml}$ and 1.5 to $3.7 \mathrm{ml}$ (range : 0.5 to $6.0 \mathrm{ml}$ ), respectively.

Highest volume was in winter. Variations of semen volume among breeds were reported previously (Ahmed et al., 1992). This is in agreement with Raja and Rao (1982). Repeated collection of semen will produce a large volume with low density. Volume increases with the advancement of age of the bull up to 4-5 years. Along with other parameters, semen volume and sperm concentration provide a gross estimate of reproductive performance of bulls (Alam and Hurtado, 1982). Season affects the characteristics of semen (Igboeli et al., 1987). Djimde and Weniger (1986) reported seasonality in semen volume, the largest being collected in summer in crossbred cattle. But we observed higher semen volume in spring and winter (Fig. 1). December - February is winter in Bangladesh and cold temperature might influence semen production. Other workers did not find any seasonal variation on semen volume in Bos taurus (Koivisto et al., 2008); Bos indicus (Chacon et al., 2002); Bubalus bubalis (Koonjaenak et al., 2007). 


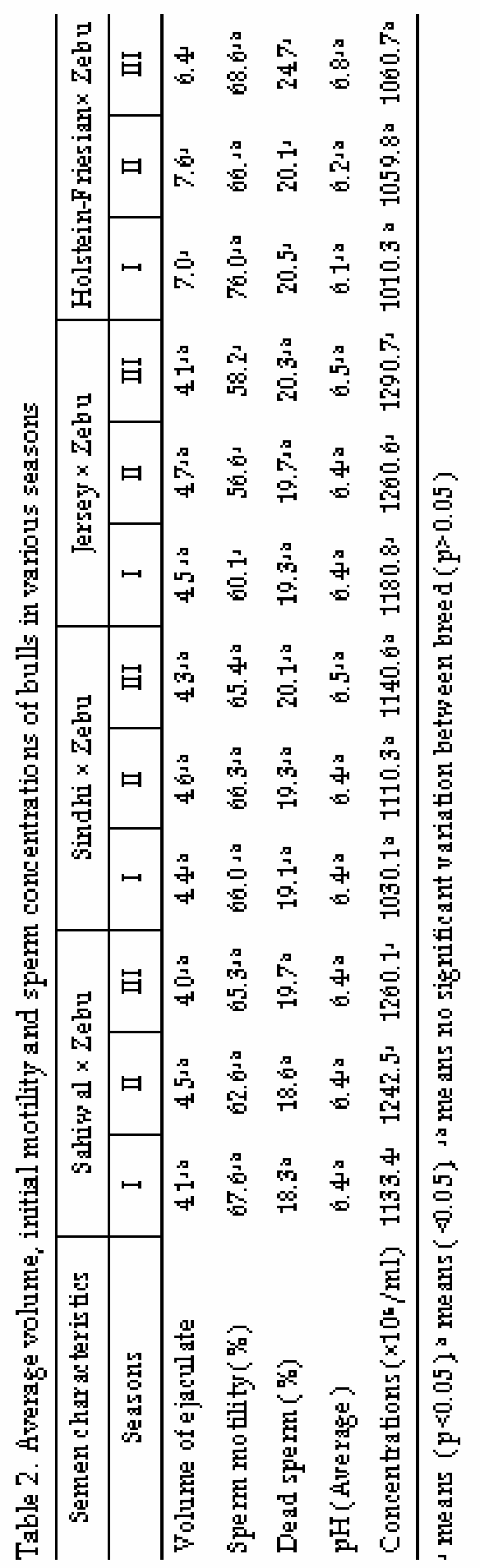




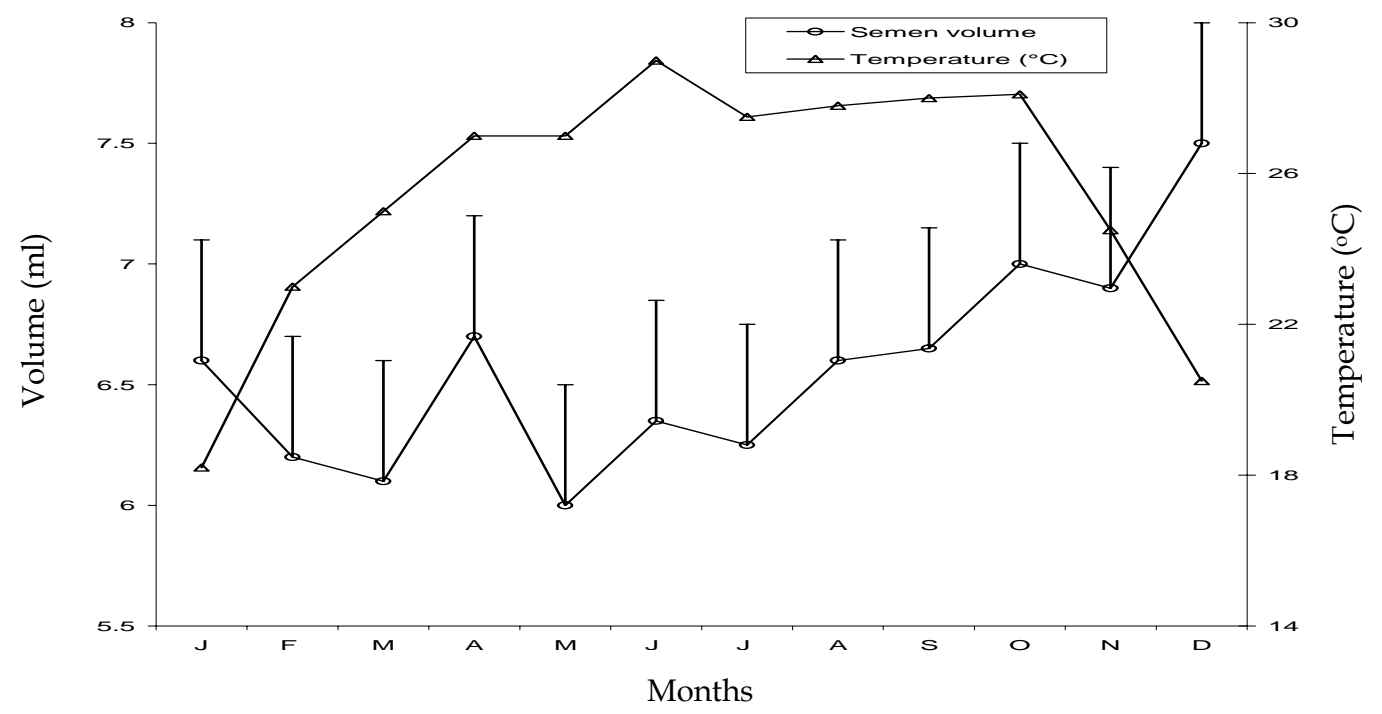

Fig. 1. Monthly variations of semen volume in AI bulls

\section{Motility}

The highest percentage of motile sperm $(66.2-76.0 \%)$ was in the HolsteinFriesian $\times$ Zebu bulls and Jersey $\times$ Zebu showed the lowest $(\mathrm{p}<0.05)$ percentage $(56.6$ - $60.1 \%)$. Motility of sperm is important for fertilization of oocytes and sustains embryonic development (Foote, 2003). Significant $(p<0.05)$ seasonal variation was also evident. The highest motility was in rainy season and lowest in winter (Fig. 2). These results agree with those of Mukherjee and Banerjee (1980); Saxena and Tripathi (1981); Igboeli et al. (1987). But Ahmed et al. (1992) reported higher motility in November to March. This variation could be caused by the age of animals, climate and management. Significantly higher forward motility of sperm has been reported in Bos taurus and Bos indicus bulls in winter (Koivisto et al., 2008).

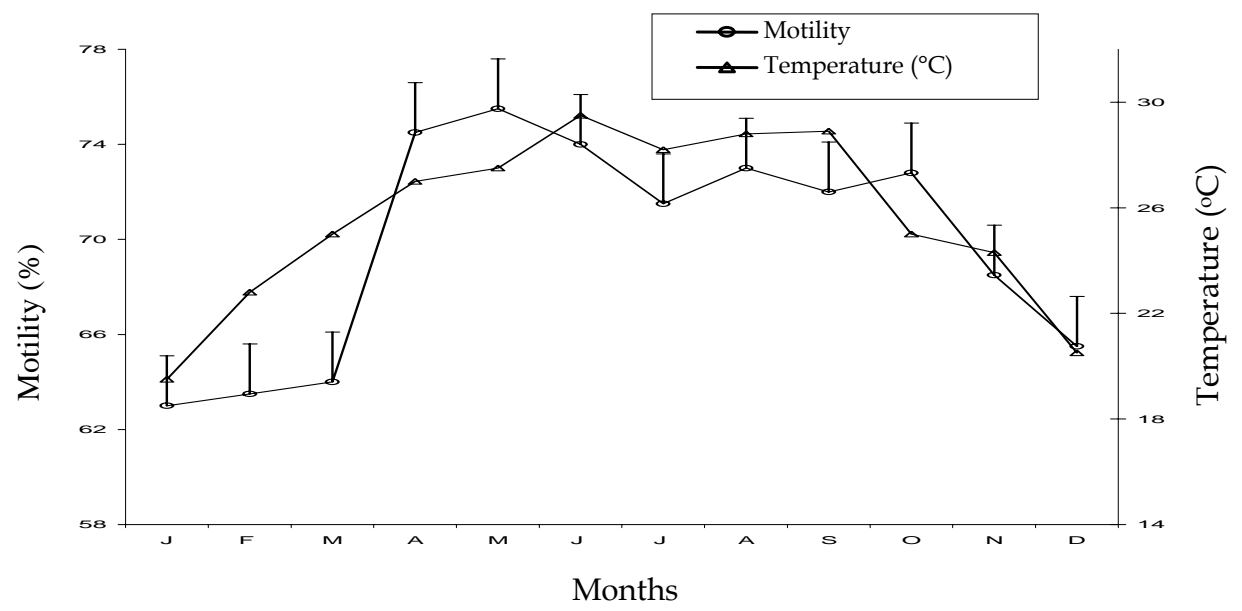

Fig. 2. Monthly variations of motility (\%) in AI bulls 


\section{Concentrations}

The highest concentrations (1000 million/ml) of sperm were found in Jersey $x$ Zebu bulls in summer, in agreement with Ahmed et al. (1992). But the concentration of sperm was lower in other breeds, in agreement with Djimde and Weniger (1986). Our results also agreed with Koivisto et al. (2008) where in Bos indicus, the highest concentration of sperm was in summer, but in Bos taurus the highest was in spring. The average concentration of sperm was higher during winter and lowest in rainy season (Fig. 3). Season had no effect on buffalo bull sperm concentration but it increased significantly with the age of the animals (Koonjaenak et al., 2007).

\section{Live and dead sperm}

The highest $(p<0.05)$ percentage $(24.7 \%)$ of dead sperm was found in summer in the Holstein-Friesian $\times$ Zebu (Table 2). The percentage of dead sperm in other breeds were 18.4 -19.8. Significantly major sperm defects were recorded in Bos taurus and Bos indicus (Koivisto et al., 2008). There is significant $(\mathrm{p}<0.05)$ difference between Sindhi $\times$ Zebu and Jersey $\times$ Zebu. Fig. 4 shows that the percentage of dead sperm was higher in summer and lowest in rainy season. This agrees with Kim et al. (1983); Tomar et al. (1985). Heat stress and other adverse climatic condition cause the highest percentage of dead sperm. In a study in buffalo, highest percentages of normal sperm were found in summer. This number decreased with age, and was affected by season (Koonjaenak et al., 2007).

$p H$

Average $\mathrm{pH}$ was $6.1-6.5$. The highest $\mathrm{pH}$ was found in summer. These results are in accordance with Mukherjee and Banerjee (1980). Lowering of $\mathrm{pH}$ with lactic acid was demonstrated to immobilize bull sperm (Acott and Carr, 1984; Carr et al., 1985). The $\mathrm{pH}$ of seminal plasma ranges from 6.7 to 7.4 , which is common in the domestic species (Roberts, 1986) and has the potential to neutralize vaginal acid. The $\mathrm{pH}$ value did not differ significantly between breeds and season.

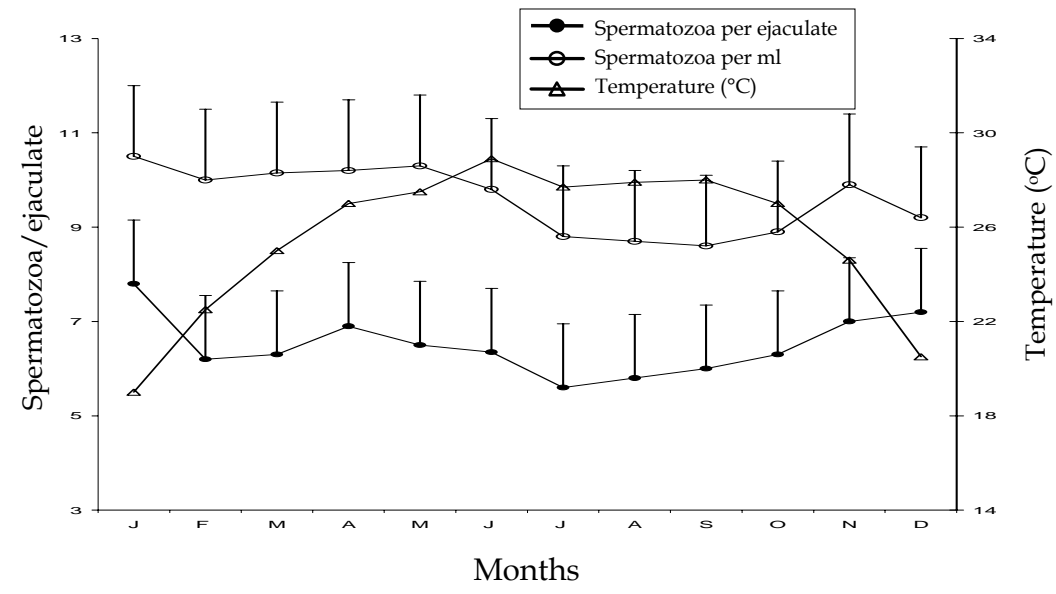

Fig. 3. Monthly variations of sperm output of AI bulls 
Igboeli et al. (1987) found best quality semen during rainy season (April August) and lowest in dry season (December - March). The authors suggested that lower temperature and abundant forage in the rainy season might influence semen production. Kim et al. (1983); Ibrahim et al. (1983) closely support the present findings. The variations obtained in the present study with many other reports might be due to variation in environment, climate and management. In domestic animals, some sperm defects are associated with subfertility or infertility, while other sperm defects affect fertility moderately when the recommended doses of sperm are used in AI (Andersson et al., 1990). Sperm concentration decreases when bulls are utilized excessively. It has been reported that sperm concentration falls, with an increase of primary sperm abnormalities in testicular degeneration (Bloom, 1978). For insemination purposes the AI authority should provide 5-10 million sperm/dose (Den Daas et al., 1998; Haard and Haard, 2000).

The breeding soundness evaluations used in Bangladesh are traditional, which grossly identify the abnormal bulls. Successful fertilization cannot be attributed solely to the number of normal sperm but more especially to their functional competence. Assessment of sperm function and fertility at molecular, cellular and whole-animal levels is needed to predict fertility of bulls that are producing apparently normal sperm. The tests employed for these assessments are flow cytometry in conjunction with fluorescent techniques, electronic cell counting, and computer-assisted image area analysis (Kastelic and Thundathil, 2008; RodriguezMartinez, 2008; Petrunkina et al., 2007).

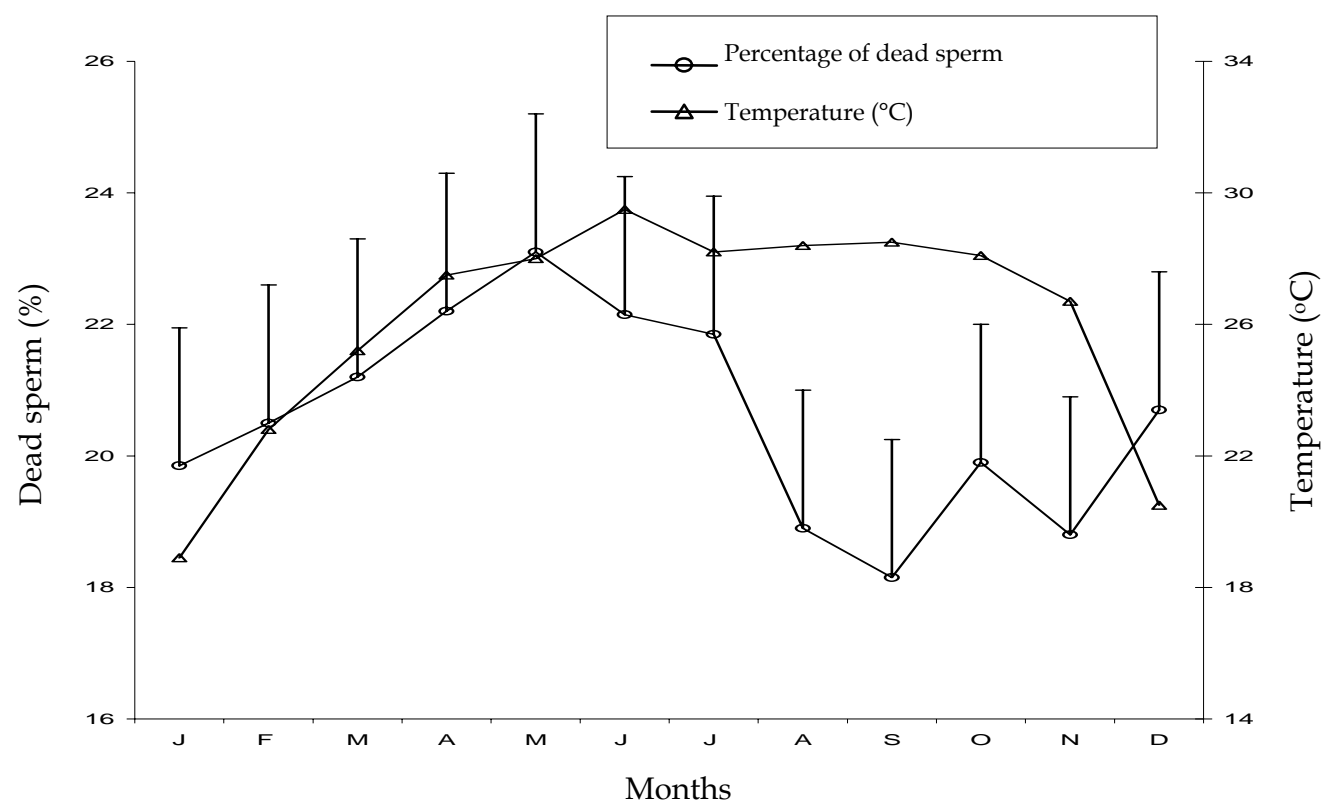

Fig. 4. Monthly variations of dead sperm (\%) in AI bulls 


\section{References}

Abaigar T, Holt W, Harrison R, Del Barrio G 1999: Sperm subpopulation in boar (Sus scrofa) and gazelle (Gazella dama mhorr) semen as revealed by pattern analysis of computer-assisted motility assessments. Biological Reproduction $6032-41$.

Acott TS, Carr DW 1984: Inhibition of bovine spermatozoa by caudal epididymal fluid. II. Interaction of $\mathrm{pH}$ and a quiescence factor. Biological Reproduction 30 926-935.

Ahmed JU, Shamsuddin M, Alam MGS 1993: Breeding soundness of bull used for Artificial Insemination in Bangladesh. Bangladesh Journal of Agricultural Science 20 225-232.

Ahmed Z, Islam TS 1987: Cattle breeding programme through artificial insemination in Bangladesh. Central Cattle Breeding Station, Savar, Dhaka, Bangladesh pp. 61.

Alam MGS, Hurtado RFC 1982: Testicular hypoplasia syndrome due to chromosome aberration. Indian Veterinary Medical Journal 2 55-60.

Almaquist JO 1978: Bull semen collection procedures to maximize output of sperm. Proceeding $7^{\text {th }}$ Technical Conference on Artificial Insemination and Reproduction, National Association of Animal Breeds; MO, USA pp. 33-36.

Andersson M, Vierula M, Alanko M 1990: Three types of acrosomal aberrations of bull spermatozoa and their relation to fertility. Acta Veterinarian Scandinavian 31 175-179.

Arthur GH, Noakes DE, Pearson H 1982: Veterinary Reproduction and Obstetrics. $6^{\text {th }}$ edn. The English language book Society and Balliere Tindall, London pp. 517-519.

Bane 1952: Case study on the technique of hemocytometric determination of sperm motility and sperm concentration in bull semen. Cornell Veterinarian 42 518-531.

Barth AD, Oko RJ 1989: Abnormal Morphology of Bovine Spermatozoa. Ames: Iowa State University Press pp. 8-1 7.

Barth AD 2007: Evaluation of potential breeding soundness of the bull. In: Youngquist RS, Threlfall WR (eds), Current Therapy in Large Animal Theriogenology 2. Saunders Elsevier, Philadelphia. pp. 228-240.

Bloom E 1978: The corkscrew sperm defect in Danish bulls of possible indicator of nuclear fallout. Nordic Veterinary Medicine 30 1-8.

Brito LF, Silva AE, Unanian MM, Dode MA, Barbosa RT, Kastelic JP 2004: Sexual development in early- and late-maturing Bos indicus and Bos indicus x Bos taurus crossbred bulls in Brazil. Theriogenology 62 1198-1217.

Carr DW, Usselman MC, Acott TS 1985: Effects of pH, lactate, and viscoelastic drag on sperm motility: a species comparison. Biological Reproduction 33 588-595.

Chacón J, Pérez E, Rodríguez-Martínez H 2002: Seasonal variations in testicular consistency, scrotal circumference and spermiogramme parameters of extensively reared Brahman (Bos indicus) bulls in the tropics. Theriogenology 58 41-50

Chenoweth PJ, Ball L 1981: Breeding soundness evaluation in bulls: In current therapy in Theriogenology. DA Morrow (edn). WB, Saunders Company. Philadelphia, London Toronto pp. 330-339.

Comhaire FH, Huysse S, Hinting A, Vermeulen L, Schoonjans F 1992: Objective semen analysis: has the target been reached? Human Reproduction 7 237-241. 
Den Daas JL, De Jong G, Lansbergen LM, Van Wagtendonk-de Leeuw AM 1998: The relationship between the number of spermatozoa inseminated and the reproductive efficiency of individual dairy bulls. Journal of Dairy Science 81 1714-1723.

Djimde M, Weniger JH 1986: Semen quality in relation to genotype and season in tropics of Bangladesh. Animal Research and Development 23 116-127.

Elliott FI 1978: Semen evaluation. Physiology of Reproduction and Artificial Insemination of Cattle. $2^{\text {nd }}$ edn. GW Salisbury, N L VanDemark, JR Lodge WH (edn), Freeman Company, San Francisco, USA pp. 400-427.

Engelken TJ 2008: The development of beef breeding bulls. Theriogenology 70 573-575.

Foote RH, 2003: Fertility estimation: a review of past experience and future prospects. Animal Reproduction Science 75 119-139.

Haard MC, Haard MGM 2000: Account of an attempt to estimate the dose-response for individual bulls in commercial AI-industry. Proceeding $14^{\text {th }}$ International Congress on Animal Reproduction, Stockholm, Sweden 280 \& 156.

Herman HA, Michell JR, Doak GA 1994: The artificial insemination and embryo transfer of dairy and beef cattle: A handbook and laboratory manual, $8^{\text {th }}$ edn. Interested Publishers Company, INC, Danville, Llinois, USA pp. 45-55.

Ibrahim MAR, Rahman MA, Toth BL, Abdin M 1983: Effect of season and bacterial contamination on semen quality freezability and fertility of Hungarian Simmental artificial insemination bulls. Acta Veterinaria Hungarica 31 81-85.

Igboeli GLN, Nwaklor, Orjii BI, Onuora GI 1987: Seasonal variation in the semen characteristics of Muturo (Bos-brachceros bulls). Animal Reproduction Science 14 31-38.

Kastelic JP, Thundathil JC 2008: Breeding soundness evaluation and semen analysis for predicting bull fertility. Reproduction in Domestic Animals 43 368-373 (Suppl. 2)

Kastelic JP, Cook RB, Coulter GH 2000: Scrotal / testicular thermoregulation in bulls. In: Chenoweth PJ (ed.), Topics in Bull Fertility. International Veterinary Information Service, http://www.ivis.org.

Kim CK, Chung YC, Kim SH 1983: Studies on reproductive capacity of Korean native bulls. Effect of age, season, and collection frequencies on semen characteristics in bulls. $5^{\text {th }}$ World Conference on Animal Production, August 14-19 2.

Koivisto MB, Costa MT, Perri SH, Vicente WR 2008: The Effect of Season on Semen Characteristics and Freezability in Bos indicus and Bos taurus Bulls in the Southeastern Region of Brazil. Reproduction of Domestic Animals 10 1439-1531.

Koonjaenak S, Chanatinart V, Aiumlamai S, Pinyopumimintr T, Rodriguez-Martinez H 2007: Seasonal variation in semen quality of swamp buffalo bulls (Bubalus bubalis) in Thailand. Asian Journal of Andrology 9 92-101.

Mortimer ST 2000: CASA- Practical aspects. Journal of Andrology 21 515-524.

Mukherjee DP, Banerjee GC 1980: Genetics and breeding of farm animals. Published by Oxford and IBM Publishing Company, Calcutta pp. 297-301.

Ott RS 1986: Breeding soundness evaluation of bulls. In: Morrow D A(Ed), Current therapy in Theriogenology, WB Sounders Company. Philadelphia, USA 2 125-136. 
Parkinson TJ 2004: Evaluation of fertility in natural service bulls. The Veterinary Journal 168 215-229.

Petrunkina AM, Waberski D, Günzel-Apel AR, Töpfer-Petersen E 2007: Determinants of sperm quality and fertility in domestic species. Reproduction 134 3-17.

Quintero-Moreno A, Mir'o J, Rigau AT, Rodr'iguez-Gil JE 2003: Identification of sperm subpopulations with specific motility characteristics in stallion ejaculates. Theriogenology 59 1973-1990.

Raja MS, Rao AR 1982: Note the semen characteristics of cross-breed purebred bulls. Indian Journal of Animal Science 52 230-232.

Roberts SJ 1986: Veterinary Obstetrics and Genital Diseases, $3^{\text {rd }}$ edn. Stephen Roberts, Woodstock, VT, USA pp. 622, 709.

Rodriguez-Martinez H 2008: Estimation of fertility in breeding bulls. Proceeding: $15^{\text {th }}$ International Congress on Biotechnology in Animal Reproduction (ICBAR), 6-7 August, Bangladesh Agricultural University, Mymensingh, Bangladesh pp. 87-106.

Salisbury GW, VanDemark NL, Lodge JR 1978: Physiology of Reproduction and Artificial Insemination of Cattle. San Francisco: WH Freeman \& Co. pp. 428-441.

Sane CR, Luktuke SN, Kaikini AS, Hukeri VB, Deshpande BR, Velhankar DP 1994: Artificial insemination of cattle. In: Sane CR, Hukeri VB, Marathe MR (Edn). Reproduction in Farm Animals (Theriogenology). Varghese Publishing House, USA pp. 524-89.

Santos MD, Torres CAA, Guimaraes JD, Pereira JC, Machado GV 1998: Semen and scrotal circumference of zebu bulls fed with two levels of concentrate and lipids. Revista Brasileira de Zootecnia - Brazilian Journal of Animal Science 27 627-632.

Saxena VB, Tripathi SS 1981: Seasonal variation in the incidence of sperm morphological abnormalities in dairy bulls regularly used for Artificial Insemination. British Veterinary Journal 143 312- 317.

Tomar SN, Sharma CK, Shukla SN 1985: Semen production in relation to the age of Holstein-Friesian $\times$ Haryana bulls. Indian Veterinary Journal 62 499-501. 